\title{
The effect of social media and lecturer's direct instructions on students' digital sculpting skills
}

\author{
Tiantada Hiranyachattada ${ }^{1, *}$ and Kampanat Kusirirat ${ }^{2}$ \\ 1,2,* Program of Animation and Digital Media, Bansomdejchaopraya Rajabhat University, Bangkok, Thailand \\ For correspondence: tiantada.hi@bsru.ac.th
}

\begin{abstract}
:
As the technology continues to advance, it becomes imperative to use technology as a tool for learning. In learning 3D animation field, digital sculpting skills are one of the important skills for students; however, each student has different learning ability, which are obstacles in doing digital sculpting. In this research, we use the social media and lecturer's direct instructions to promote students' digital sculpting skills. In methodology, we create a learning management plan of our learning method, then let the students practise digital sculpting by using video sharing and group discussion via Facebook group, together with lecturer's direct instructions both inside and outside the classroom. Analysis shows that the students have improved their digital sculpting skills and are satisfied with this learning method. Social media and lecturer's direct instructions act as a useful learning method and instrument for students' discussion, practising and researching.
\end{abstract}

Keywords: digital sculpting, direct instruction, learning skills, social media, undergraduate students

\section{Introduction}

Nowadays, the society is in transition, from a society that gives importance to information, socalledinformation-based society to a society that gives importance to knowledge or knowledge-based society. Knowledge-based society is the key to drive our country which is based on having knowledge and theadvancement of information technologyto be fundamental for further action. The knowledge-based society creates a system of producing new invention which is integrated into a network of production. In addition, data information and communication technology tools will easily and quickly access to knowledge.

As the technology continues to advance, it is found that Thailand internet users use internet for nearly 10 hours on work or school days, and 11 hours on holidays. Also, YouTube, Line, Facebook are still the top 3 social platforms of the Thais (Electronic Transactions Development Agency, 2019; Leesanguansuk, 2019). Popular social media among university students such as Facebook and YouTube are widely used in higher education and with this instrument of educational innovation, lecturers will need to know and learn how to use social media in their courses to help the students learn more and achieve learning objectives (Seechaliao, 2014). At present, the role of social media in education are the effectiveness of social media as a learning tool with the use of technology in the subjects, including both inside and outside of classrooms (Moran et al., 2011). Also, the social media can facilitate university learning activities (Irwin et al., 2012). Moreover, it can help students connect with the experts on specific field topics, the lecturer can communicate with the students to make announcements and provides students with useful information and helps them in research process (Dlamini, 2019). Also, video sharing that is distributed through social media is not just an online video that is made for entertainment or marketing but it turns out that video sharing becomes an 
influential media. Online video sharing is also seen as optimistic media, express opinions and expressions; therefore, it becomes a popular tool for studying (Samarak et al., 2015).

Direct instruction is one of the learning methods, which focuses on strength training while studying and aiming to practice skills and knowledge for students, and is a method based on the theory of behavioral psychology. The importnat part of direct instruction is the lecturer must give the suggestion to the students when they have problems both in classroom and in Facebook group. This learning method can help students develop their learning sustainably since it gives the students knowledge and skills so they can use those to achieve thier practical results (Mulkhum and Mulkhum, 2007). Also, the new generation of lecturer need to be able to integrate technology into learning method in the classroom to create a new learning environment for students, to combine skills and face to real situations.

In learning 3D animation field, digital sculpting is a topic that focuses on creating 3D model or 3D digital sculpting with digital sculpting software such as Zbrush (Pixologic, 2020) to use in animation work. In traditional digital sculpting subject in the classroom, the lecturer will demonstrate the digital sculpting in front of the class and the students will look and mimic the technic from the lecturer and practise at the same time. However, each student has different learning ability, so all students cannot catch up the lecturer and finish their work at same time, which make them not be able to do the digital sculpting as the lecturer expect such as using wrong sculpting workflow, using wrong software instructions, misunderstanding some tools, and not be able to use the 3D model. Also, practice time in the class is only 4 hours per week, which is not enough to make students receive sufficient practice skills.

From theabove, using video sharing through Facebook group and lecturer's direct instructions can be used for learning and cultivate students to take advantage of social media, not only changing the lecturer role to advisor, but also lead to be student-centered; to learn by themselves, which is consistent with proactive learning management. This learning method use the digital sculpting learning management plan as a guideline for learning digital sculpting, then let the students practise independently anywhere and anytime by using video sharing through social media to demonstrate, practise digital sculpting and have group discussion with the lecturer and with their classmates, in order to develop their digital scupting skills to achieve the most effective goals.

\section{Method}

The main objective of this research are to study the effect using social media with lecturer's direct instructions and to find out the students' satisfaction. The participants of the research are 36 undergraduate students studying in digital sculpting subject in the Department of Animation and Digital Media. This class is a must for freshmen in every first semester and is mandatory for all students pursuing the Bachelor of Science in Animation and Digital Media. The digital sculpting skill test will be given to the students to assess their digital scupting practical skills in 6 assignments. The students are also assessed from the observation by the lecturer both in the classroom and social media, and the satisfaction questionnaires will be given to the students for the feedback of this learning method.

Throughout the class, we represent the learning management plan, based on content management system (CMS) (Mauthe and Thomas, 2004) as shown in table 1, delivered to the students for both in class and after class. We define the digital sculpting skill criteria to be divided into 6 topics: 1) the subtool usage, 2) polygon shape correction and polygon dividing techniques, 3) correct character proportion, 4) character details and beauty, 5) painting, and 6) the time usage in each assignment. 
Table 1. Digital sculpting learning management plan summarization

\begin{tabular}{|c|c|}
\hline Step & Details \\
\hline Step 1. Pre- requisite & $\begin{array}{l}\text { - The lecturer reviewed the relevant earlier knowledge from } \\
\text { the past semester such as the anatomy of humans or animals } \\
\text { - The lecturer created Facebook group and invited all } \\
\text { students to discuss in the Facebook group }\end{array}$ \\
\hline Step 2. Learning objectives & $\begin{array}{l}\text { - The lecturer informed learning objectives of digital } \\
\text { sculpting subject and course details to the students }\end{array}$ \\
\hline $\begin{array}{l}\text { Step } 3 \text {. Content } \\
\text { representation }\end{array}$ & $\begin{array}{l}\text { - The lecturer prepared and analysed the content with a clear } \\
\text { order process and prepared various digital sculpting } \\
\text { examples and questions during teaching to the students in } \\
\text { classroom } \\
\text { - The lecturer used video sharing to demonstrate digital } \\
\text { sculpting } \\
\text { - The lecturer asked questions to check the students' } \\
\text { understanding } \\
\text { The lecturer summarized the main points of the study at the } \\
\text { end of the content and linked the content for next week }\end{array}$ \\
\hline Step 4. In-class practising & $\begin{array}{l}\text { - The students practice digital sculpting independently from } \\
\text { video sharing with the lecturer checking the students' work } \\
\text { closely, as well as correcting errors in the students' } \\
\text { assignment }\end{array}$ \\
\hline Step 5. Out-class practising & $\begin{array}{l}\text { - The students practiced independently in Facebook group } \\
\text { together with video sharing and the assignment from the } \\
\text { lecturer } \\
\text { - The students and the lecturer were able to discuss the } \\
\text { problems or errors that they had found in Facebook group } \\
\text { - The lecturer lets the students do digital sculpting skill test }\end{array}$ \\
\hline Step 6. Review & $\begin{array}{l}\text { - The lecturer reviewed all of the content that the students } \\
\text { had learned in this subject }\end{array}$ \\
\hline
\end{tabular}

\section{Findings}

From the method, the digital sculpting class is 4 hours per week, Facebook group is the social media, which the lecturer creates with the video to make the students follow up, practise and discuss about the digital sculpting as shown in figure 1. Also, the students discuss the digital sculpting techniques or problems found with the lecturer though Facebook group as shown in figure 2.

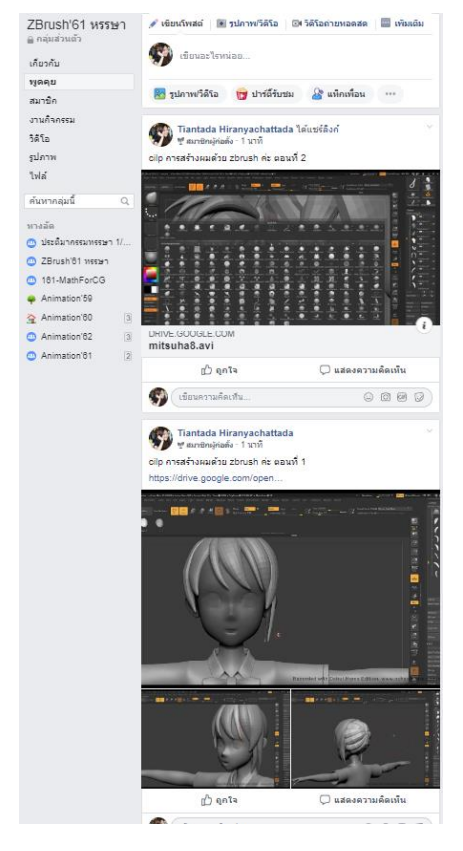

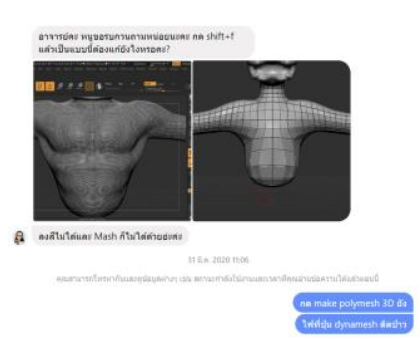

(a) Discussing about the digital sculpting techniques 


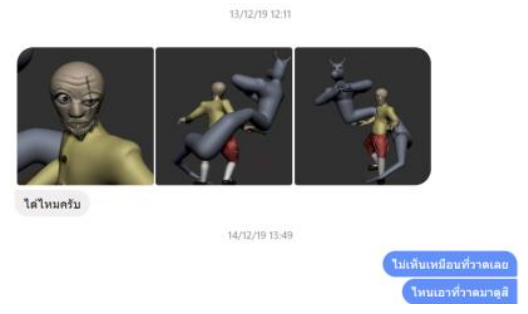

(b) Discussing about the design and beauty

Figure 1. Digital sculpting Facebook group

Figure 2. Students' discussion with the lecturer

Also, we compare the students' work from the traditional learning with our learning method in figure 2 , which can be seen that the students' work was developed in various skill criteria such as polygon shape correction and polygon dividing techniques and character proportion as can be seen in figure 3 .

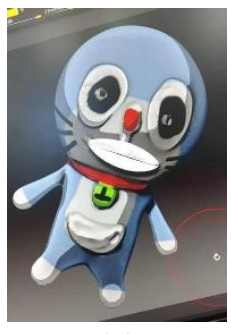

(a)

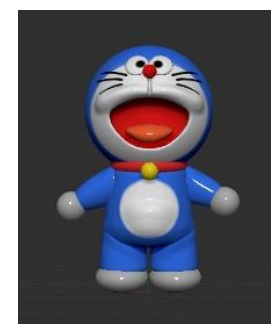

(b)

Figure 3. Comparing students' work (a) Traditional learning (b) Our learning method

We evaluate students' digital skills from 6 assignments which can classified into 3 groups, the details of each assignment and students' average scores of each assignment are shown in table 2.

Table 2. Students' assignment details and average scores

\begin{tabular}{clc}
\hline Assignment No. & \multicolumn{1}{c}{ Details } & Score (SD)/(30) \\
\hline 1 & Beginner: The simple shape modelling & $15.64(2.22)$ \\
2 & Beginner: The simple shape modelling with sub-tools & $17.47(1.68)$ \\
3 & Intermediate: SD scale character & $19.31(1.41)$ \\
4 & Intermediate: SD scale character with sub-tools & $20.53(1.84)$ \\
5 & Hard: Real human scale muscle & $20.25(2.20)$ \\
6 & Hard: Real human scale with sub-tools & $23.44(1.81)$ \\
\hline
\end{tabular}

The digital sculpting skill assignment in each week shows that the students have developed their scores from the first assignment. Considering the scores in 6 criteria of digital sculpting skills, we found that the students have improved the details and beauty of the sculpting clearly but the sculpting time has been developed a little bit. The character proportion and painting texture, which they already have the skills from the earlier subject can help the students apply these skills in digital sculpting. The sub-tool usage, polygon-shaped correction, and polygon-dividing techniques are the criteria that the students are able to do well in the first period of learning and still be until the last assignment. The comparison of the students' scores development in each criteria of digital sculpting skills is shown in figure 4. 


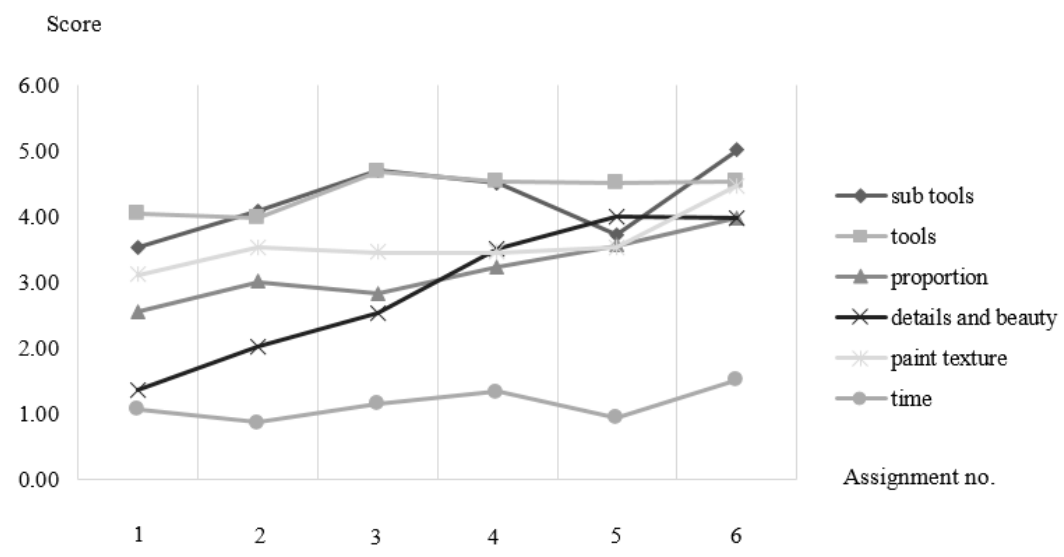

Figure 4. The comparison of the students' scores development in each criteria

The observation of students' skills shown in table 3, we found that the students' practical skills with total average score at 2.23 is in a high level. Analysing each statement and we found that students did the digital sculpting well but they lack the knowledge in applying and creating, which must be promoted in order to make the students continue to create better work.

Table 3. Observation of students' practical skill score $(n=36)$

\begin{tabular}{|c|c|c|}
\hline Statement & Score (SD) & Quality level \\
\hline \multicolumn{3}{|l|}{ Students' behaviour } \\
\hline 1. Participation in learning & $2.67(0.48)$ & Excellent \\
\hline 2. Consistency in submitting assignments & $1.72(0.88)$ & Good \\
\hline 3. Skills in using video sharing and social media as learning tools & $2.86(0.35)$ & Excellent \\
\hline 4. Ability to solve digital sculpting problems by themselves & $2.36(0.72)$ & Good \\
\hline 5. Ability to apply knowledge and to have creativity in work & $1.56(1.27)$ & Good \\
\hline Average & $2.23(0.74)$ & Good \\
\hline \multicolumn{3}{|l|}{ Students' digital sculpting skills } \\
\hline 6. Ability to separate the sub-tools & $2.31(0.47)$ & Good \\
\hline $\begin{array}{l}\text { 7. Ability to use polygon-shaped correction and polygon-dividing } \\
\text { techniques }\end{array}$ & $2.14(0.98)$ & Good \\
\hline 8. Ability to analyse the proportion of the assignment & $2.03(0.77)$ & Good \\
\hline 9. Ability to create digital sculpting work with details and beauty & $1.75(1.30)$ & Good \\
\hline 10. Ability to paint the texture of the model & $2.64(0.84)$ & Excellent \\
\hline 11. Students use suitable time in each assignment & $0.97(0.84)$ & Moderate \\
\hline Average & $1.97(0.76)$ & Good \\
\hline Total average & $2.10(0.75)$ & Good \\
\hline
\end{tabular}

Finally, we provided the satisfaction questionnaire to the students to evaluate their feedback of our learning method, the result is shown in table 4. It is found that the average score of the appropriate digital sculpting assignment is at the highest, this shows that learning management plan can help the students to understand digital sculpting content further, time division in learning has the lowest average score, which shows that the time usage was not enough for the students to practise and learn, which depends on the credit of the subject. 
Table 4. Students' satisfaction results $(n=36)$

\begin{tabular}{|c|c|c|}
\hline Statement & Score (SD) & Quality level \\
\hline 1. I clearly understand the learning strategy & $4.50(0.51)$ & Excellent \\
\hline $\begin{array}{l}\text { 2. Classroom activities are appropriate and relevant to the learning } \\
\text { content }\end{array}$ & $3.92(0.73)$ & Good \\
\hline 3. The learning environment is interesting & $4.11(0.82)$ & Good \\
\hline 4. I have participated in the learning process & $4.53(0.51)$ & Excellent \\
\hline 5. I clearly understand the learning activities & $4.53(0.51)$ & Excellent \\
\hline 6. I have the appropriate time in learning & $3.86(0.83)$ & Good \\
\hline $\begin{array}{l}\text { 7. I use available learning resources such as the internet, social } \\
\text { network, etc. to improve my digital sculpting skills }\end{array}$ & $4.64(0.49)$ & Excellent \\
\hline $\begin{array}{l}\text { 8. I have exchanged ideas both in the classroom and through social } \\
\text { media }\end{array}$ & $4.47(0.51)$ & Excellent \\
\hline 9. I feel that the activities are creative & $3.94(0.75)$ & Good \\
\hline 10. Students are consistently practising digital sculpting skills & $4.31(0.47)$ & Good \\
\hline $\begin{array}{l}\text { 11. The activities help the students to develop their digital sculpting } \\
\text { skills }\end{array}$ & $4.58(0.50)$ & Excellent \\
\hline 12. The activities help me to understand the content & $4.67(0.48)$ & Excellent \\
\hline $\begin{array}{l}\text { 13. While practising, I am able to realize my own } \\
\text { mistakes and correct them }\end{array}$ & $4.58(0.50)$ & Excellent \\
\hline 14. The content is appropriate for the students' ability & $4.56(0.50)$ & Excellent \\
\hline 15. Assignments are appropriate for me & $4.89(0.32)$ & Excellent \\
\hline 16. The content is modern and up to date & $4.17(0.74)$ & Good \\
\hline 17. The content creates creativity and can be applied & $4.25(0.73)$ & Good \\
\hline 18. The content is useful for an animation career & $3.89(0.85)$ & Good \\
\hline 19. I can access the content easily and quickly & $4.75(0.44)$ & Excellent \\
\hline 20. Assessment covers all content. & $4.86(0.35)$ & Excellent \\
\hline Aver & $4.40(0.58)$ & Good \\
\hline
\end{tabular}

\section{Conclusion}

In conclusion, the uses of e-learning technology, which focuses on the internet technology in the past present in the form of online learning that can support the learning activities and help students to access subject matter (Nasution et al., 2020). This can solve the problems of the different learning ability of the students. Moreover, the purpose of using Facebook group is to let students share their techniques and discuss the sculpting techniques with their classmates or solve found problems from various ways when they do digital sculpting, as the problems will improve the students' learning skills. The problems must be corrected immediately before the students misunderstand. This learning process, when combined with direct instructions from the lecturer can help to achieve the goals efficiently.

Considering the digital sculpting skill average score, we found that the average score is developing continuously in every assignment. Considered each criteria of digital sculpting skills, it appears that the practice skill scores that have been improved are details and beauty, proportion and paint texture, which caused by organizing activities that focus on practising and learning of the students to work in sequence with steps. Also, using social media, the Facebook group, helps students further understand the steps of practising. Using sub-tools, tools usage and time usage scores are fluctuate alternately because these criteria depend on the complexity of the 3D model which are different in each assignment. 
The students' satisfaction evaluation shows the responses received from the students indicating that they are satisfied with the content of the video sharing and benefit from these learning methods, which help them to have better learning outcomes and boost their learning experience. Students also considered the e-learning approach useful as it allows them to learn anytime and anywhere. Moreover, it has been revealed that the students prefer to study by a combination of e-learning and direct instructions, since it is useful and helpful to their learning progress. For the lecturers, it shows that the key factors for their continued satisfaction with e- learning are the quality of information, task technology, system quality, confirmation, usefulness, achievement value, and utility value (Khan and Setiawan, 2019).

\section{Suggestions}

Our suggestions from this research are the lecturer should teach the students about reliable screening from social media, to study from various references and to compare them to get the most accurate and convincing information. Our recommendation for next research is to find out the learning method that can develop all criteria in digital sculpting skills or to find other interesting learning methods to be implemented with technology.

\section{Acknowledgements}

The author would like to express sincere thanks to Program of Animation and Digital Media, Research and Development Institute Bansomdejchaopraya Rajabhat University and the Faculty of Science and Technology, Bansomdejchaopraya Rajabhat University, Bangkok, Thailand.

\section{References}

Dlamini, K., (2019) “The Role of Social Media in Education" https://www.lcibs.co.uk/the-role-of-social-media-in-education, (accessed December 2019)

Electronic Transactions Development Agency, (2019) “The use of internet in Thailand." https://www.etda.or.th, (accessed December 2019)

Irwin, C., Ball, L., Desbrow, B., \& Leveritt, M., (2012). Students' perceptions of using Facebook as an interactive learning resource at university. Australasian Journal of Educational Technology, 28(7), 1221-1232.

Khan M. L. H. and Setiawan A., (2019). The impact of E- learning on higher education perception, skills, critical thinking and satisfaction. Journal of Physics: Conference Series, 1375, 012-084.

Leesa-nguansuk, S., (2019) "Thailand in social media world's top 10" https://www.bangkokpost.com/learning/advanced/1255403/thailand-in-social-media-worlds-top-10, (accessed December 2019)

Mauthe A. and Thomas P., (2004). Professional Content Management Systems: Handling Digital Media Assets. Germany, John Wiley \& Sons.

Moran, M., Seaman, J., \& Tinti-Kane., H., (2011). Teaching, Learning, and Sharing: How today's higher education faculty use social media. Boston, MA: Pearson Learning Solutions.

Mulkhum, S. and Mulkhum, A. (2007). Learning Management Methods: To develop knowledge and skills. Bangkok, Parbpim Printing.

Nasution A., Hasairin A., Arwita W., (2020). Biology Students Perception of Learning Ethnobotany based on Electronic Learning (E-Learning). Journal of Physics: Conf. Series, 1462, 012-064.

Pixologic, (2020) "ZBrush at a Glance" https://pixologic.com/features/about-zbrush.php, (accessed January 2020)

Seechaliao, T., (2014). Lecturers' Behaviors And Beliefs About The Use Of Social Media In Higher Education: A Study At Mahasarakham University In Thailand. Journal of International Education Research, 10(2), 155-160. 